\title{
Improving sand with microbial-induced carbonate precipitation
}

1 Rahim Shahrokhi-Shahraki MSC Department of Water Engineering, Shiraz University, Shiraz, Iran

2 Seyed Mohammad Ali Zomorodian PhD

Associate Professor, Department of Water Engineering, Shiraz University, Shiraz, Iran
$3 \quad$ Ali Niazi PhD Associate Professor, Department of Biological Engineering, Shiraz University, Shiraz, Iran

4 Brendan C. O'Kelly PhD, FTCD, CEng, CEnv, MICE Associate Professor, Department of Civil, Structural and Environmental Engineering, Trinity College Dublin, Dublin, Ireland
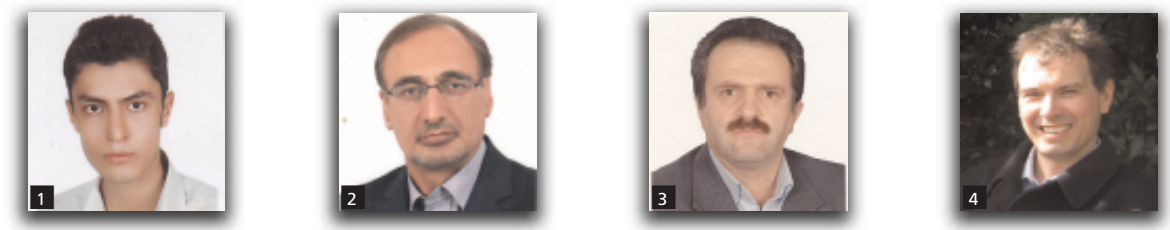

Microbial-induced carbonate precipitation using urea hydrolysis is a relatively new improvement technique for granular soils. An important factor in achieving uniform calcite deposition (and hence consistent improvements in geomechanical properties) throughout the treated soil mass is the protocol adopted for injecting the reagents of ureolytic bacteria, urea and calcium. This paper reports a laboratory study investigating a technique to treat two loose medium quartz sands using different injection strategies. Staged injection including retention periods, and with a pressure head applied during injection of the bacterial cell solution, proved most effective. Sand specimens were treated using different concentrations of bacterial cell and urea-calcium chloride solutions and for a single injection cycle. Measured strength and stiffness values from unconfined compression tests ranged from 50 to $240 \mathrm{kPa}$ and from 6 to $56 \mathrm{MPa}$, respectively. Permeability coefficient values were reduced by up to approximately one order of magnitude. Hence, a single injection cycle adhering to the proposed treatment method did not significantly affect the drainage capacity of the sand media. Greater improvements in stiffness and strength were achieved for lower bacterial cell and higher cementation solution concentrations, with a higher molarity of urea (non-equimolar solutions) proving even more effective. These findings were confirmed by scanning electron microscope observations.

\section{Introduction}

Traditional grouting methods for ground improvement employ particulate (cement/bentonite) or chemical grouts that can be rather expensive and environmentally unfriendly (Ivanov and Chu, 2008). Recently, novel grouting techniques (e.g. see DeJong et al., 2006, 2010; Khatami and O'Kelly, 2013; Stabnikov et al., 2011; Whiffin et al., 2007) have been developed to treat unsaturated coarse-soils by stimulating natural processes. One of these methods, termed biogrouting, has shown some promise in soil cementation via microbially induced carbonate precipitation (MICP). This approach mimics natural processes by depositing calcite $\left(\mathrm{CaCO}_{3}\right)$ on the soil grains, thereby increasing the material's stiffness/strength and reducing its erodibility. The microbiological process relies on ureolytic (non-pathogenic) bacteria such as Sporosarcina pasteurii or Bacillus pasteurii to hydrolyse urea in the presence of calcium ions, resulting in the precipitation of calcite crystals.

1. $\mathrm{CO}\left(\mathrm{NH}_{2}\right)_{2}+2 \mathrm{H}_{2} \mathrm{O} \stackrel{\text { urease }}{\longrightarrow} 2 \mathrm{NH}_{4}{ }^{+}+\mathrm{CO}_{3}{ }^{2-}$

2. $\mathrm{Ca}^{2+}+\mathrm{CO}_{3} \stackrel{2-}{\text { yields }} \rightarrow \mathrm{CaCO}_{3}(\mathrm{~s})$

The application of the MICP technique has shown promise in various fields, including improvement in the stiffness/strength of sandy soil (Rong et al., 2012; van Paassen, 2009; Whiffin et al., 2007); reductions in foundation settlement (DeJong et al., 2010) and soil permeability (Dennis and Turner, 1998; Seki et al., 1998); liquefaction mitigation (DeJong et al., 2006; Montoya et al., 2012); strengthening of concrete and remediation of cracks (Achal et al., 2010; Bang et al., 2001; Ramachandran et al., 
2001); microbially enhanced oil recovery (Nemati et al., 2005); dust control (Meyer et al., 2011); and wastewater treatment (Hammes et al., 2003).

In ground treatment applications for sandy soil, the deposition of calcite over the grain surfaces and around the grain contacts (the latter produces more direct benefit to the geomechanical properties through interparticle cementation) creates a sandstone-like material. In principle, MICP treatment protocols can be tailored to produce a more targeted deposition of calcite around the grain contacts, with the porosity decreasing by less than $10 \%$ (Viganotti, 2014). Hence, significant improvements in the geomechanical properties can be achieved while maintaining permeability. Alternatively, for high concentrations of component chemicals, the calcite precipitation can occur as more concentrated in the pore voids as well as over the full surface area of the grains, producing significant reductions in the volume of the pore space and the sizes of the pore throats. In this case, more dramatic reductions in permeability can be achieved (Yasuhara et al., 2011).

Table 1 summarises previous experimental laboratory studies on MICP soil treatment reported in the literature. The technique has also been successfully trialled at full scale on a gas pipeline installation project in the Netherlands (van Paassen, 2011). In advance of this project, laboratory testing was performed on MICP-treated soil (gravel) columns to estimate the strength improvement possible. A summary of these test results is included in Table 1. From the limited available data, key factors governing the degree of strength improvement achievable by the MICP technique include environmental circumstances (i.e. temperature, $\mathrm{pH}$, oxygen level, degree of saturation, chemical composition of resident pore fluids), the soil grading and surface characteristics of the constituent solids, the concentration of the urea-calcium chloride $\left(\mathrm{CaCl}_{2}\right)$ cementation solution and the number of treatment cycles/injections. For instance, a rise of $10^{\circ} \mathrm{C}$ over the temperature range $5-35^{\circ} \mathrm{C}$ causes the urease activity to increase by a factor of 2.4 (van Paassen, 2009). No urease activity was observed for a soil temperature below $5^{\circ} \mathrm{C}$. Microbiologically induced carbonate mineral precipitation occurs for a $\mathrm{pH}$ range of $8 \cdot 3-9 \cdot 0$, for which urease activity remains high (StocksFischer et al., 1999). For a similar calcite content, higher soil strength can be achieved when the MICP treatment is performed at a low degree of saturation (Cheng et al., 2013). The degree of permeation of the bacterial cell solution over the soil treatment depth is dependent on the minimum pore size: more specifically, the relative dimensions of the bacteria and pore voids/throats.

Several combinations of urea and $\mathrm{CaCl}_{2}$ solution concentrations have been investigated for the production of calcite precipitate. For instance, Okwadha and $\mathrm{Li}$ (2010) investigated different combinations of 0.33 and $0.67 \mathrm{M}$ urea and $0.0025,0.025$ and $0 \cdot 25 \mathrm{M}$ calcium $\left(\mathrm{Ca}^{2+}\right)$ solution concentrations. They reported that for the same bacterial cell concentration, greater amounts of calcite were deposited for higher urea and $\mathrm{Ca}^{2+}$ concentrations, with the optimum combination from those investigated reported as $0.67 \mathrm{M}$ urea and $0.25 \mathrm{M} \mathrm{Ca}^{2+}$. In order to determine the maximum concentration of urea and $\mathrm{Ca}^{2+}$ that can be effective for MICP performed in a single treatment application, Whiffin (2004) investigated several equimolar urea- $\mathrm{Ca}^{2+}$ concentrations in the range $0 \cdot 5-3.0 \mathrm{M}$. Her results indicated that, up to $1.5 \mathrm{M}$, the amount of precipitated calcite increased in direct proportion to the urea- $\mathrm{Ca}^{2+}$ solution concentration. Above $1.5 \mathrm{M}$, the amount of precipitated calcite was found to reduce. In the study by Al-Thawadi (2008), equimolar urea- $\mathrm{Ca}^{2+}$ solution concentrations in the range $0 \cdot 125-2 \cdot 0 \mathrm{M}$ were continuously flushed up through sand columns. The results showed that the greatest amount of precipitated calcite and the highest mobilised strength occurred for the $0.5 \mathrm{M}$ cementation solution. Al Qabany et al. (2011) also investigated different equimolar urea- $\mathrm{CaCl}_{2}$ concentrations in the range $0 \cdot 1-1 \cdot 1 \mathrm{M}$, in order to study the effect of chemical concentration on the calcite deposition patterns. The observed patterns indicated that the use of lower chemical concentrations applied over multiple injections produced more uniform cementation. Yasuhara et al. (2011) reported that the

\begin{tabular}{|c|c|c|c|c|c|}
\hline Reference & Soil type & $\begin{array}{c}\text { Cementation } \\
\text { concentration: M }\end{array}$ & $\begin{array}{c}\text { Number of injection } \\
\text { cycles }\end{array}$ & UCS: kPa & $\begin{array}{l}\text { Permeability } \\
\text { reduction: \% }\end{array}$ \\
\hline Whiffin et al. (2007) & $\begin{array}{l}\text { Itterbeck sand, } \\
D_{50}=0.165 \mathrm{~mm}\end{array}$ & $1 \cdot 1$ & 1 & $0-500$ & $22-75$ \\
\hline Yasuhara et al. (2011) & Sand & $0 \cdot 5,1 \cdot 0$ & $\begin{array}{c}\text { 4-8 for UCS } \\
1-4 \text { for permeability }\end{array}$ & $373-1500$ & $60-70$ \\
\hline van Paassen (2011) & Gravel & NR & $1-4$ & $15-40$ & NR \\
\hline Palmén (2012) & $\begin{array}{l}\text { Quartz sand, } \\
D_{50}=0.85 \mathrm{~mm}\end{array}$ & $N R$ & $\begin{array}{l}1 \\
5\end{array}$ & $\begin{array}{c}200 \\
2600\end{array}$ & $N R$ \\
\hline Soon et al. (2013) & Sand, $D_{50}=0.52 \mathrm{~mm}$ & 0.25 & 8 & 50 & 90 \\
\hline
\end{tabular}

NR, not reported; UCS, unconfined compressive strength. 
cementation solution concentration is a key factor in modifying the strength and permeability of MICP-treated sand. They investigated 0.5 and $1.0 \mathrm{M}$ (equimolar) urea- $\mathrm{CaCl}_{2}$ solutions, with the $1.0 \mathrm{M}$ solution producing a greater increase in strength and reduction in the permeability coefficient for the test sand. Although many research papers have been published on the MICP process, the current authors' review of the literature indicated that none of these studies specifically considered the effect of the bacterial cell solution concentration on the strength and hydraulic properties of the treated soil.

Upscaling biomediated soil improvement from laboratory element tests to field scale is generally more complex than for other grouting methods, and an integration of geotechnical, ecology, microbiology and geochemistry knowledge is required (Ivanov and Chu, 2008). Practical challenges include creating favourable/ optimum environmental and hydrological conditions in situ for the MICP process, ensuring calcite deposition occurs over a wide volume of ground and not just adjacent to reagent injection points, maintaining the necessary retention periods for reagents within the ground mass under treatment and also the recovery/ recycling of unused reagents. Potential limitations for the practical application of MICP for ground improvement include the production of undesirable by-products, especially ammonia (see Equation 1), and the reversibility of the process (Ivanov and Chu, 2008). Also, improvements in the geomechanical properties and (or) permeability coefficient reductions achievable by MICP generally occur at slower rates compared with other grouting methods.

The aims of this experimental laboratory study are to investigate

- a suitable method of injecting the reagents to achieve uniform calcite precipitation throughout columns of loose sand

- the effect of injecting different concentrations of bacterial cell and cementation solutions on the stiffness, strength and hydraulic properties of the treated sands.

For the latter, the authors investigated the effects of equimolar and non-equimolar urea- $\mathrm{CaCl}_{2}$ cementation solutions on the properties of the treated sand at an ambient laboratory temperature of $20 \pm 2^{\circ} \mathrm{C}$. The effects were assessed in terms of measured unconfined compressive strength (UCS), stiffness and permeability coefficient values, and also from scanning electron microscope (SEM) observations. These results are discussed and linked to the current understanding in the literature.

\section{Materials}

\subsection{Soil type}

Compatibility between the soil grain characteristics and bacteria size is an important factor for MICP treatment. The soil pores should be of sufficient size to allow the transportation of bacteria $0 \cdot 5-3.0 \mu \mathrm{m}$ in length (Mitchell and Santamarina, 2005), with
$50-400 \mu \mathrm{m}$ reported as the most favourable soil particle size range for bacterial activity in the pores (Rebata-Landa, 2007). In the present study, two clean medium sands were investigated (test materials $\mathrm{A}$ and $\mathrm{B}$ in Figures 1 and 2 and Table 2); both comprised angular to sub-angular quartz grains. Sand B was slightly coarser than sand A, although the grain-size distributions for up to $40 \%$ passing were approximately similar (see Figure 2).

\subsection{Micro-organism and culture medium}

For the MICP process, Sporosarcina pasteurii (PTCC 1645) was used as the urease-positive bacterium. Following the work of Whiffin et al. (2007), an ammonium yeast-extract medium comprising $10 \mathrm{~g}$ of ammonium chloride and $20 \mathrm{~g}$ of yeast extract per litre of deionised water was selected for bacterial growth. For optimum urease activity, the $\mathrm{pH}$ value of the medium was adjusted to $\mathrm{pH} 8 \cdot 5$ (Stocks-Fischer et al., 1999) by slowly adding $4 \mathrm{M}$ sodium hydroxide prior to inoculation. The culture medium was sterilised by autoclaving at $121^{\circ} \mathrm{C}$ for a $15 \mathrm{~min}$ period.

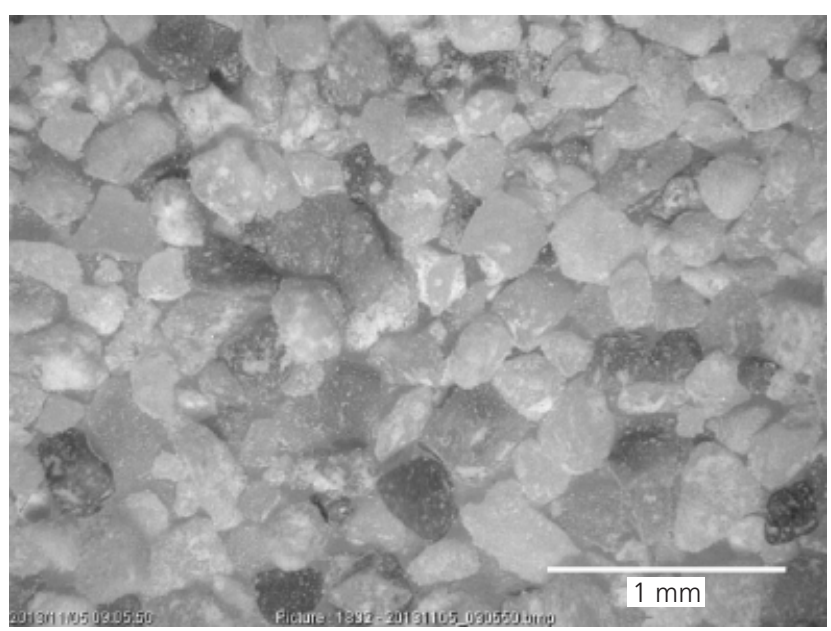

(a)

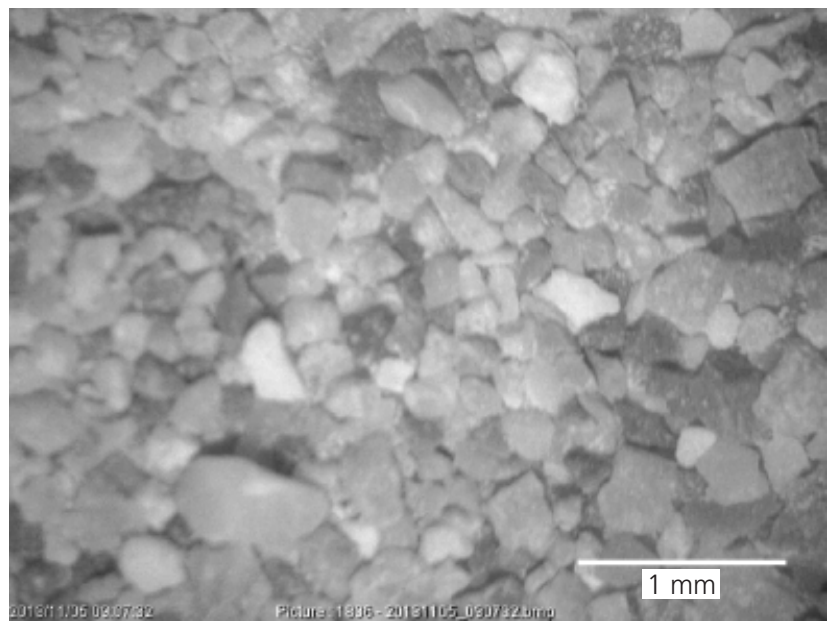

(b)

Figure 1. Particle shape characteristics: (a) sand A; (b) sand B 


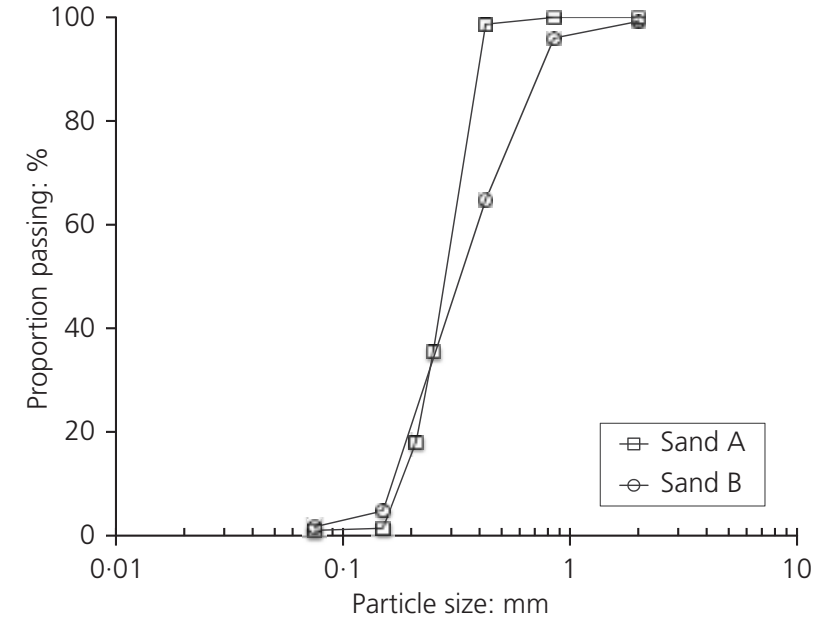

Figure 2. Grading curves for test sands

\begin{tabular}{lcc}
\hline \multirow{2}{*}{ Soil property } & \multicolumn{2}{c}{ Sand material } \\
\cline { 2 - 3 } & $\mathrm{A}$ & $\mathrm{B}$ \\
\hline $\mathrm{G}_{\mathrm{s}}$ & 2.66 & 2.65 \\
$D_{10}: \mathrm{mm}$ & 0.18 & 0.16 \\
$D_{50}: \mathrm{mm}$ & 0.28 & 0.34 \\
$D_{60}: \mathrm{mm}$ & 0.31 & 0.41 \\
$D_{90}: \mathrm{mm}$ & 0.39 & 0.72 \\
Coefficient of uniformity & 1.72 & 2.56 \\
Coefficient of curvature & 1.03 & 0.88 \\
Maximum void ratio & 1.01 & 0.98 \\
Minimum void ratio & 0.63 & 0.60 \\
Density index: \% & 33 & 23
\end{tabular}

Table 2. Some physical properties of the test sands

\subsection{Preparation of the bacterial cell solution}

A seed culture was produced by transferring a small amount of the S. pasteurii lyophilised culture into $100 \mathrm{ml}$ of the culture medium and allowing culture growth to occur at $30^{\circ} \mathrm{C}$ over a $24 \mathrm{~h}$ period. This mixture was then cooled and stored at $4^{\circ} \mathrm{C}$ prior to its use. The main culture medium was inoculated with the seed culture $(10 \% \mathrm{v} / \mathrm{v})$ and incubated aerobically under agitation at $30^{\circ} \mathrm{C}$ over a $48 \mathrm{~h}$ period, by the end of which the cells had reached maximum population (i.e. a stationary phase). After the required bacterial growth had occurred, the cells in the culture medium were harvested at a temperature of $4^{\circ} \mathrm{C}$ by centrifugation for $10 \mathrm{~min}$ at $5000 \mathrm{~g}$. The harvested cells were then washed twice in sodium phosphate buffer $0 \cdot 1 \mathrm{M}(\mathrm{pH} 7)$ to remove metabolic waste and any metabolism produced during the bacterial growth phase. 'Metabolism' refers to all chemical reactions that occurred within the bacterial cells. Metabolic wastes are substances that cannot be used by the bacterial cells (i.e. surplus or have lethal effect) and must be excreted. Bacterial cells at the desired concentration were resuspended in nutrient broth (NB)-urea solution comprising $3 \mathrm{~g}$ of $\mathrm{NB}, 20 \mathrm{~g}$ of urea, $10 \mathrm{~g}$ of ammonium chloride and $2 \cdot 12 \mathrm{~g}$ of sodium bicarbonate per litre of deionised water. The $\mathrm{pH}$ value of the bacterial cell solution was adjusted to $\mathrm{pH} 6$ using $4 \mathrm{M}$ hydrochloric acid prior to autoclaving. To investigate the effect of the bacterial cell concentration on the properties of the treated sands, solutions were prepared in the laboratory at $\mathrm{OD}_{600}$ values of $0 \cdot 8,1.5$ and $3 \cdot 0$, where $\mathrm{OD}_{600}$ is the optical density of bacteria measured by a spectrophotometer at a wavelength of $600 \mathrm{~nm}$. Using Equation 3, the cell concentrations $\left(Y\right.$, in $\mathrm{ml}^{-1}$ ) corresponding to these $\mathrm{OD}_{600}$ values were estimated at approximately $6 \times 10^{7}, 1 \times 10^{8}$ and $4 \times 10^{8}$ cells/ $\mathrm{ml}$, respectively (Ramachandran et al., 2001).

3. $Y=8.59 \times 10^{7} \times \mathrm{OD}_{600} 1.3627$

Stocks-Fischer et al. (1999) reported that bacterial cell solutions that have $\mathrm{OD}_{600}$ values in the range $0 \cdot 8-1 \cdot 2$ produced higher urease activity. The lower-bound value of this range, along with approximately two and four times this value (i.e. $\mathrm{OD}_{600}=1.5$ and $3 \cdot 0$, respectively), were investigated in the present study. Approximate estimates of the total microbial population present per gram of in situ soil near the ground surface are of the order of $10^{6}-10^{9}$ (Mitchell and Santamarina, 2005; Pichan and O'Kelly, 2014) and $10^{8}-10^{10}$ (Ehrlich, 1996). The microbial population generally includes Bacillus, Arthrobacter and Pseudomonas bacteria, with their concentrations decreasing with depth below ground surface level. The preparation in situ or under laboratory conditions of solutions having $\mathrm{OD}_{600}>3$ is very difficult, if not impossible. Hence, bacterial cell solutions having such high $\mathrm{OD}_{600}$ values were not investigated in the present study.

\subsection{Preparation of cementation solutions}

Six different combinations of urea and $\mathrm{CaCl}_{2}$ concentrations (Table 3) were investigated as cementation solutions for sand $\mathrm{A}$. The non-equimolar urea- $\mathrm{CaCl}_{2}$ cementation combinations 3 and 6 listed in Table 3 were prepared by dissolving the same masses of urea and $\mathrm{CaCl}_{2}$ in distilled water. Considering that the molecular weights of anhydrous $\mathrm{CaCl}_{2}$ and urea are 111 and $60 \mathrm{~g} / \mathrm{mol}$, respectively (i.e. molecular weight ratio of 1.85 ), for these cementation solutions the urea molarity was 1.85 times that of the $\mathrm{CaCl}_{2}$. Hence, to produce cementation combination 6 ( $1.85 \mathrm{M}$ urea-1 $\mathrm{M} \mathrm{CaCl}_{2}$ ), $111 \mathrm{~g}$ of urea and $111 \mathrm{~g}$ of $\mathrm{CaCl}_{2}$ was dissolved per litre of distilled water. The same approach was used to determine the required masses of urea and $\mathrm{CaCl}_{2}$ in producing cementation combinations 4 and 5 reported in Table 3 .

\section{Experimental methods}

\subsection{Specimen preparation}

Test specimens of sands A and B were prepared for MICP treatment followed by strength testing using a method adopted from Ismail (2000). The test specimens were formed using PVC split moulds (50 $\mathrm{mm}$ inner diameter by $170 \mathrm{~mm}$ long), with the 


\begin{tabular}{|c|c|c|c|c|c|c|}
\hline $\begin{array}{l}\text { Cementation } \\
\text { combination }\end{array}$ & $\begin{array}{l}\text { Urea: } \\
\text { M }\end{array}$ & $\begin{array}{c}\mathrm{CaCl}_{2} \text { : } \\
\mathrm{M}\end{array}$ & $\begin{array}{l}\text { Stiffness: } \\
\text { MPa }\end{array}$ & $\begin{array}{l}\text { UCS: } \\
\mathrm{kPa}\end{array}$ & $\begin{array}{l}\text { Permeability coefficient: } \\
\mathrm{m} / \mathrm{s}\end{array}$ & $\begin{array}{c}\text { Reduction of } \\
\text { permeability: \% }\end{array}$ \\
\hline 1 & $0 \cdot 10$ & $0 \cdot 10$ & $6 \cdot 5$ & 50 & $2 \cdot 1 \times 10^{-4}$ & 50 \\
\hline 2 & $0 \cdot 25$ & $0 \cdot 25$ & $5 \cdot 6$ & 75 & $1.8 \times 10^{-4}$ & 57 \\
\hline 3 & 0.46 & $0 \cdot 25$ & 30 & 110 & $1.4 \times 10^{-4}$ & 67 \\
\hline 4 & 0.25 & 0.50 & $9 \cdot 7$ & 80 & $1.7 \times 10^{-4}$ & 60 \\
\hline 5 & $1 \cdot 00$ & $0 \cdot 50$ & 49 & 180 & $8 \cdot 1 \times 10^{-5}$ & 81 \\
\hline 6 & $1 \cdot 85$ & $1 \cdot 00$ & 56 & 240 & $2.6 \times 10^{-5}$ & 94 \\
\hline Control (untreated) & 0 & 0 & - & - & $4.2 \times 10^{-4}$ & - \\
\hline
\end{tabular}

Table 3. Some properties of MICP-treated sand A using a bacterial concentration of $1 \times 10^{8}$ cells $/ \mathrm{ml}$

two halves of these moulds held together during the preparation and curing stages using hose clamps. A rubber membrane was fitted in contact with the inner wall surface of each assembled mould. A layer of filter paper was placed at the bottom of each mould. Then, $385 \mathrm{~g}$ of dry sand was air pluviated into each specimen mould in three layers of equal thickness. The sand was slowly poured from a container positioned $100 \mathrm{~mm}$ vertically above the top of each mould. After deposition, each sand layer was individually compacted by gently tapping around the outer wall of the mould. After performing numerous trials, a consistent methodology was established to produce $140 \mathrm{~mm}$-long sand specimens. This specimen preparation method produced a loose sand state (density index values of $33 \%$ and $23 \%$ for sands A and $\mathrm{B}$, respectively) having a dry unit weight of $14 \mathrm{kN} / \mathrm{m}^{3}$.

A $30 \mathrm{~mm}$-deep gravel filter was placed above each sand specimen prepared as described above. For the injection process, each mould was fitted with end caps, which were sealed using tape, and positioned vertically. For the strength tests, the clamps were released, and the two halves of each split mould separated to free the treated specimens, which remained laterally enclosed by their rubber membranes. For the permeability tests, the same specimen preparation method was used except that intact PVC tubes of the same dimensions were employed instead of split moulds. The permeability tests were performed on the treated specimens while still contained in these tubes. To check reproducibility, test specimens were prepared in triplicate for each experimental condition investigated in this study.

The specimens' length-to-diameter (aspect) ratio of 2.8:1 was greater than the standard 2:1 ratio used in triaxial compression testing (BS 1377: BSI, 1990). In maintaining a test specimen diameter of $50 \mathrm{~mm}$, a decision was made to adopt the larger aspect ratio of $2 \cdot 8: 1$ for the purpose of investigating the degree of success achievable for different injection strategies in uniformly transporting the reagents over greater distances. In triaxial compression testing, the standard aspect ratio of $2: 1$ provides a zone of near-uniform strain/stress within the mid-third of the specimen length (i.e. $\sim 33 \mathrm{~mm}$ gauge) (Jardine et al., 1984; O'Kelly and Naughton, 2008), within which shear failure generally occurs. The larger aspect ratio of $2 \cdot 8: 1$ adopted in the present investigation provided a longer central gauge length (zone of uniform strain/stress) of $\sim 73 \mathrm{~mm}$. In other words, the larger aspect ratio would not have adversely affected (and may have enhanced) the measurement of the material's shear resistance.

\subsection{Injection strategies}

Successful MICP treatment in sand requires the injection of the bacterial cell and cementation solutions followed by their permeation through the entire sand specimen/bed. The most important factor in achieving an even deposition of precipitated calcite throughout the sand mass is the uniform distribution/ fixation of the bacterial cells. In the literature, different MICP injection strategies have been investigated for sand, including the following scenarios.

(a) Mixing the bacterial cell and cementation solutions together before injection into the sand. However, the reagents flocculate immediately, and while this approach may be considered for coarser soils (Le Métayer-Levrel et al., 1999), rapid clogging of the pore voids generally occurs for fine/ medium sand (Whiffin, 2004), rendering the treatment ineffective.

(b) Two-phase injection, in which the bacterial cell solution is injected first, followed by the cementation solution (Whiffin et al., 2007).

(c) Staged injection (Tobler et al., 2012), with or without retention periods between the injection phases. Using this approach, excessive crystal accumulation close to the injection point can be prevented from occurring and a more uniform distribution of calcite crystal formation can be achieved over a greater distance in the sand specimen/bed. More effective MICP treatment is achieved using retention periods between injection phases that allow more bacteria to be fixed into the pore void space. Retention periods also facilitate greater numbers of reactions to occur between the bacterial cell and cementation solutions (Al Qabany et al., 2011; Rong et al., 2012).

A fourth scenario that was examined in the present study but, 
to the authors' knowledge, investigations employing the following approach have not been reported in the literature.

(d) Single-phase injection (i.e. reagents injected simultaneously into the sand).

In the present study, preliminary tests were performed to investigate all four injection strategies for the $140 \mathrm{~mm}$-long sand specimens. The relative success achieved for the different approaches was similar to that reported by previous researchers, with staged injection (scenario $(c)$ ) proving the most effective. For scenario (a), the reagents flocculated immediately on mixing, and any attempt to permeate the mixture through the sand specimens rapidly caused clogging of the pore voids next to the injection points. For single-phase injection (scenario $(d)$ ), the bacterial cell and cementation solutions were simultaneously injected via separate delivery tubes into the tops of the sand specimens. Again, rapid clogging of the pore voids next to the injection points prevented any significant permeation of the mixture, which was evidenced by only the portions of the specimens nearest the injection points gaining toughness. For two-phase injection (scenario $(b)$ ), rapid flocculation and clogging of the pore voids were not observed but the toughness of the treated specimens did not significantly increase away from the injection points. A possible explanation is that during subsequent injection of the cementation solution, its downward permeation may have leached/flushed bacterial cells from the specimens via their outflows. Scenario (c) (staged injection) was investigated further as the most promising approach to achieving greater fixation of the injected bacterial cell solution in the pore voids.

The next series of tests considered both upward and downward injections through the sand specimens as well as investigating different injection rates and retention periods. It was observed that uniform strength improvement could not be achieved over the full specimen length using staged injection alone. Significant cohesion was gained over the portions of the specimens between the injection points and the specimen mid-heights (i.e. a linear distance of $\sim 70 \mathrm{~mm}$ ). However, no significant strength improvement was achieved for greater distances, with the unconfined sand in the distant halves of the treated specimens easily crumbling by hand. Similar behaviour was observed by Whiffin et al. (2007) and Rong et al. (2012), with the former reporting mobilised UCS values in the range $0-500 \mathrm{kPa}$ over the length of sand columns treated by MICP in this manner. This behaviour occurs on account of the accumulation of bacterial cells near the injection points, which hampers their transportation over greater distances along the specimen length.

The protocol adopted for the main testing programme of the present investigation was staged injection with retention periods. Given the limited distances through which the bacterial cells had been transported during the preliminary tests, it was decided to inject the bacterial cell solution under relatively high pressure via the tops of the sand specimens. After a $12 \mathrm{~h}$ retention period, the urea- $\mathrm{CaCl}_{2}$ cementation solution was injected, but without applying a pressure head (i.e. slow flow rate) in order to mitigate against possible leaching of adsorbed bacterial cells.

\subsection{One-cycle staged injection with retention periods}

For the main testing programme, the MICP treatment was applied to loose specimens of sands A and B using staged injection (downward flow), including retention periods, and with a pressure head applied during injection of the bacterial cell solution, as follows.

- The sand specimens were de-aired by permeating water of volume $\sim 2 V_{\mathrm{v}}$ down through the specimens, where $V_{\mathrm{v}}$ is the volume of the specimen pore voids, which was $130 \cdot 2 \mathrm{ml}$ for the $140 \mathrm{~mm}$-long specimens of sands A and B prepared in the manner described earlier.

- A bacterial cell solution of volume $1 \cdot 5 V_{\mathrm{v}}$ was injected into each specimen under a pressure head (initially $1.2 \mathrm{~m}$ but falling slightly over the course of the injection (Figure 3(a)), with the outflow rate of $\sim 10 \mathrm{ml} / \mathrm{min}$ from the specimen base controlled by a peristaltic pump. The purpose of the pressure head was to promote transportation of more bacterial cells and over greater distances from the injection points; in other words to achieve a more uniform distribution over the specimen length.

- After this volume of bacterial cell solution had been introduced into each specimen (now fully saturated with bacterial solution), the flow was stopped for a $12 \mathrm{~h}$ period, allowing the bacterial cells to be adsorbed by the sand grains. At the end of this retention period, the peristaltic pump was disconnected from the hydraulic line, and the bacterial cell solution was allowed to drain under gravity from the specimen base.

- Reservoirs containing the urea- $\mathrm{CaCl}_{2}$ solutions were placed directly above the specimens (i.e. applying a negligible pressure head). The cementation solutions, which had slightly lower densities compared with the bacterial cell solutions, were allowed to permeate down through the specimens, with the outflow rate of $3.0 \mathrm{ml} / \mathrm{h}$ from the base of each specimen controlled by a peristaltic pump (Figure 3(b)).

- After the urea- $\mathrm{CaCl}_{2}$ cementation solution of volume $V_{\mathrm{v}}$ had entered each specimen, the flow was stopped for a $24 \mathrm{~h}$ period to allow the bacteria to react with the cementation solution. At the end of this $24 \mathrm{~h}$ retention period, the peristaltic pump was disconnected from the hydraulic line, and each sand specimen was allowed to drain under gravity from its base.

The effect of MICP treatment using different concentrations of bacterial cell and urea- $\mathrm{CaCl}_{2}$ cementation solutions was assessed in terms of measured strength, stiffness and permeability coefficient values. SEM images were also used to evaluate the success of the staged MICP injection protocol adopted for the main testing programme as well as the formation and distribution of calcite crystals in the two treated sands. 


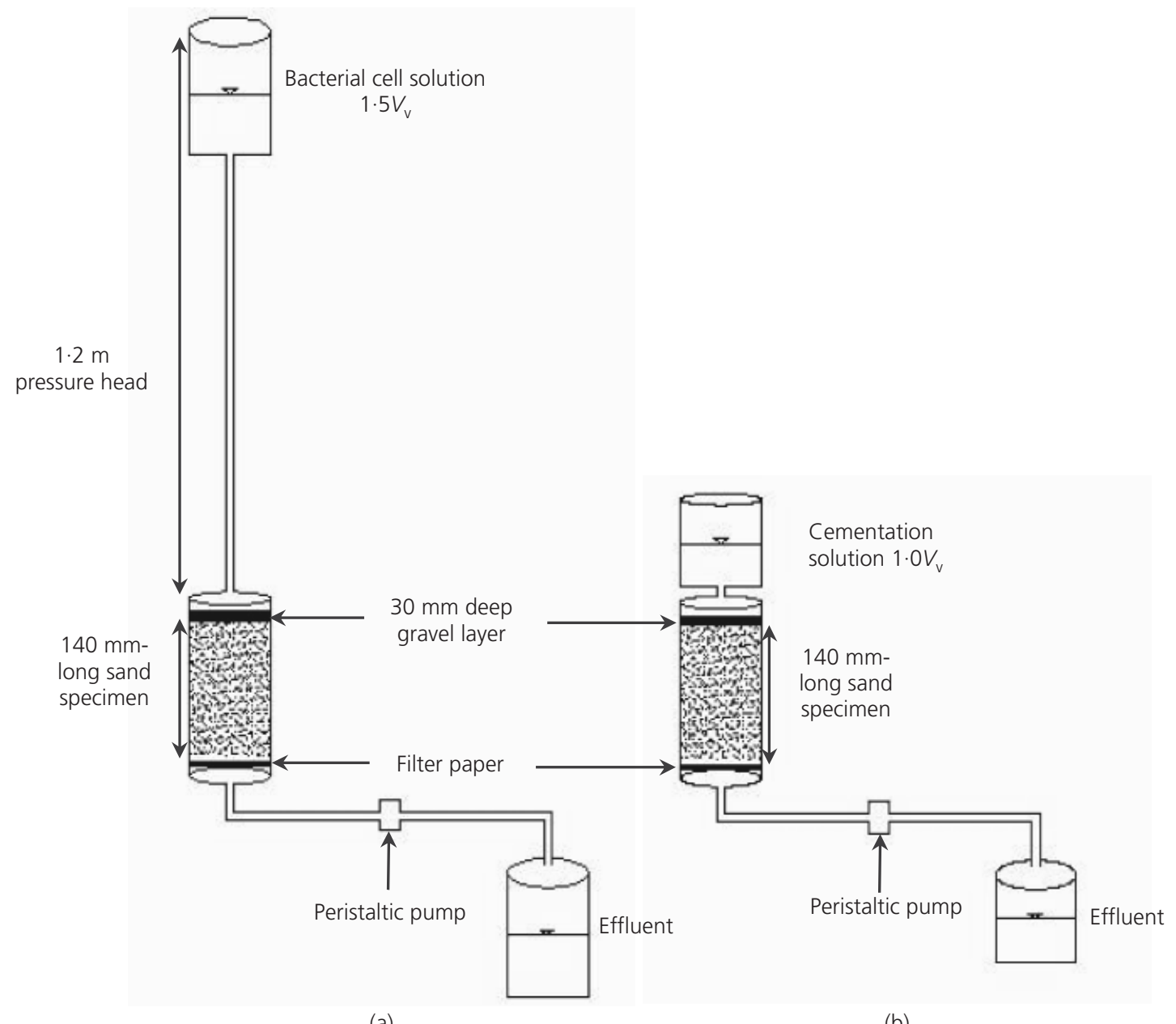

Figure 3. The MICP staged injection protocol adopted:

(a) injection of the bacterial cell solution; (b) injection of the

cementation solution

\subsection{Strength and permeability tests}

After completing the MICP treatment, the drained specimens were allowed to cure over a $21 \mathrm{~d}$ period at an ambient laboratory temperature of $20 \pm 2^{\circ} \mathrm{C}$. The specimens for strength testing were then released from their split moulds, and their ends trimmed as necessary to produce right cylinders, thereby ensuring uniform contact with the specimen loading platens. The stress-strainstrength characteristics of these specimens $(50 \mathrm{~mm}$ in diameter by $\sim 140 \mathrm{~mm}$ long) were determined in unconfined compression at an axial strain rate of $0 \cdot 36 \% / \mathrm{min}$ using an Instron apparatus. The permeability coefficient values of the cured specimens (still contained in their moulds) were determined using the falling-head method.

\subsection{SEM tests}

SEM images were obtained from horizontal sections through the top, middle and bottom portions of specimens treated with $1 \times 10^{8}$ cells $/ \mathrm{ml}$ and $1.85 \mathrm{M}$ urea $-1.0 \mathrm{M} \mathrm{CaCl}_{2}$ solutions in order to investigate the formation and spatial distribution of calcite crystals over the specimen length. These specimens were sectioned using a sharp knife. SEM images were also obtained from specimens treated with the same bacterial cell solution concentration but using $0.25 \mathrm{M}$ urea- $0.25 \mathrm{M} \mathrm{CaCl}_{2}$ cementation solution, in order to investigate the effect of different cementation solution concentrations on calcite formation. Finally, SEM images were obtained from specimens treated with the same $1.0 \mathrm{M}$ urea$0.5 \mathrm{M} \mathrm{CaCl}_{2}$ cementation solution but using $6 \times 10^{7}$ or $4 \times 10^{8} \mathrm{cells} / \mathrm{ml}$ bacterial solution concentration, in order to investigate the effect of different bacterial cell concentrations on calcite formation.

\section{Experimental results and analyses}

4.1 Strength and stiffness in unconfined compression Measures of the absolute improvements in strength and stiffness under confined compression achieved by the MICP treatment 
could not be determined since the untreated sand specimens (controls) mobilised no shear resistance. Hence, the effects of different bacterial cell and urea- $\mathrm{CaCl}_{2}$ solution concentrations were assessed by comparing the treated specimens' UCS and stiffness values. The effect of the bacterial cell solution concentration was considered first (Table 4 and Figure 4) followed by the cementation solution concentration (Table 3 and Figure 5). The UCS values were determined as the peak deviatoric stresses mobilised, which generally occurred for $0 \cdot 5-2 \%$ axial strain. The general mode of failure for the treated specimens was nearest to longitudinal splitting.

The stiffness values were determined as the gradients of the steepest, approximately linear portions of the deviatoric stressstrain plots. Each UCS and stiffness value reported in Tables 3 and 4 is the mean of the respective values measured for the three specimens tested for each experimental condition, with good reproducibility achieved; that is, similar deviatoric stress-strain plots were obtained for each set of three identically prepared and treated specimens.

All of the data in Table 4 and Figure 4 indicate that for the same cementation solution concentration but different bacterial concentrations of $6 \times 10^{7}, 1 \times 10^{8}$ and $4 \times 10^{8}$ cells $/ \mathrm{ml}$ investigated, mobilised stiffness and UCS values decreased with increasing bacterial cell concentration. The finer of the two test sands (i.e. sand A, see Table 2 and Figure 1) consistently mobilised higher stiffness and UCS values, apart from the UCS of specimens treated with the $4 \times 10^{8}$ cells $/ \mathrm{ml}$ solution. Similar findings were reported in previous studies by Ismail et al. (2002). However, it is recognised that the two test sands had slightly different grading, particle shape characteristics and densification levels (see Table 2 and Figures 1 and 2), and hence presumably different friction angles, which would also influence the shear resistances mobilised by the two sands.

Table 3 indicates that for the same bacterial concentration of $1 \times 10^{8}$ cells $/ \mathrm{ml}$, the treated specimens generally mobilised greater stiffness and UCS values for higher urea- $\mathrm{CaCl}_{2}$ solution concentrations. Similar findings have been reported by Yasuhara et al. (2011). In the present study, the lowest and highest UCS

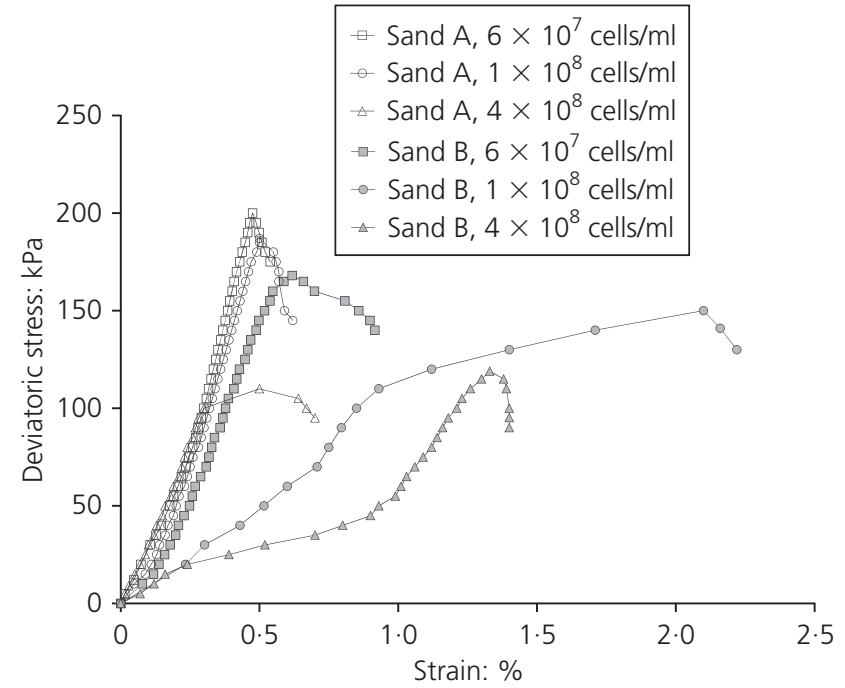

Figure 4. Deviatoric stress-strain responses of MICP-treated sand specimens using the $1.0 \mathrm{M}$ urea- $0.5 \mathrm{M} \mathrm{CaCl}_{2}$ cementation solution

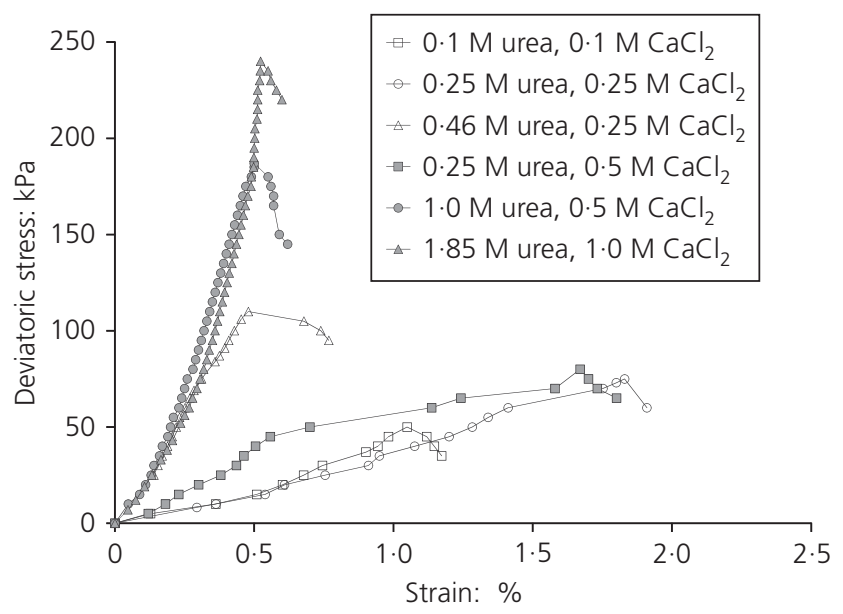

Figure 5. Deviatoric stress-strain responses of MICP-treated sand A using the $1 \times 10^{8}$ cells $/ \mathrm{ml}$ bacterial solution

\begin{tabular}{|c|c|c|c|c|c|c|}
\hline \multirow{2}{*}{$\begin{array}{l}\text { Bacterial concentration: } \\
\text { cells } / \mathrm{ml}\end{array}$} & \multicolumn{2}{|c|}{ Stiffness: MPa } & \multicolumn{2}{|c|}{ UCS: kPa } & \multicolumn{2}{|c|}{ Permeability coefficient: $\mathrm{m} / \mathrm{s}$} \\
\hline & Sand A & Sand B & Sand A & Sand B & Sand A & Sand B \\
\hline $6 \times 10^{7}$ & 59 & 37 & 200 & 168 & $5.9 \times 10^{-5}$ & $5.6 \times 10^{-4}$ \\
\hline $1 \times 10^{8}$ & 51 & 23 & 180 & 150 & $8.1 \times 10^{-5}$ & $6.3 \times 10^{-4}$ \\
\hline $4 \times 10^{8}$ & 38 & 20 & 110 & 119 & $1.2 \times 10^{-4}$ & $7 \cdot 2 \times 10^{-4}$ \\
\hline 0 (control) & - & - & - & - & $4.2 \times 10^{-4}$ & $3.1 \times 10^{-3}$ \\
\hline
\end{tabular}

Table 4. Some properties of MICP-treated sands using 1.0 M

urea- $0.5 \mathrm{M} \mathrm{CaCl}_{2}$ cementation solution 
values of 50 and $240 \mathrm{kPa}$ were mobilised for the lowest and highest solution concentrations investigated of $0.1 \mathrm{M}$ urea$0.1 \mathrm{M} \mathrm{CaCl}_{2}$ and $1.85 \mathrm{M}$ urea- $1.0 \mathrm{M} \mathrm{CaCl}_{2}$, respectively. This range of UCS values is approximately in line with that reported by Whiffin et al. (2007) and Palmén (2012) for MICP studies on sands using a single injection cycle (refer to Table 1). Although generally stiffer, higher-solution concentrations typically produced more brittle responses (Figure 5). More specifically, increasing urea molarity correlated with increasing stiffness and UCS values: for example, compare cementation combination 2 with 3 , and 4 with 5 , in Table 3 . For sand $\mathrm{A}$, the axial strain at failure $\left(\varepsilon_{\mathrm{f}}\right)$ reduced from $\sim 1.8 \%$ strain $\left(0.25 \mathrm{M}\right.$ urea- $\left.-0.25 \mathrm{M} \mathrm{CaCl}_{2}\right)$ to $0.5 \%$ strain $\left(1.85 \mathrm{M}\right.$ urea-1.0 $\left.\mathrm{M} \mathrm{CaCl}_{2}\right)$. From Figure 4 , treated sand B had consistently lower stiffness and a larger $\varepsilon_{\mathrm{f}}$ in the range $0.6-$ $2 \cdot 2 \%$, compared with $\varepsilon_{\mathrm{f}} \approx 0.5 \%$ for sand $\mathrm{A}$. It is not clear why the sand $\mathrm{B}$ specimen treated with a bacterial solution of $1 \times 10^{8}$ cells $/ \mathrm{ml}$ and $1.0 \mathrm{M}$ urea- $-0.5 \mathrm{M} \mathrm{CaCl}_{2}$ cementation solution was more ductile under compression, with $\varepsilon_{\mathrm{f}} \approx 2 \cdot 2 \%$ (Figure 4). The limited test data suggest that increasing the $\mathrm{CaCl}_{2}$ molarity, with the urea molarity remaining unchanged, does not appear to produce significant improvements in UCS: for example, compare cementation combination 2 with 4 in Table 3.

\subsection{Coefficient of permeability}

The measured permeability coefficient $(k)$ values for the MICPtreated and -untreated (control) specimens are reported in Tables 3 and 4 , with each value determined as the mean of the values measured for the three specimens tested for each experimental condition. Approximately similar $k$ value reductions have been reported in previous MICP studies on sand: for example, see data from Soon et al. (2013), Whiffin et al. (2007) and Yasuhara et al. (2011) summarised in Table 1. Compared with the controls, the $k$ values of specimens treated using the same $1.0 \mathrm{M}$ urea- $0.5 \mathrm{M}$ $\mathrm{CaCl}_{2}$ solution, but different bacterial concentrations in the range $6 \times 10^{7}$ to $40 \times 10^{8}$ cells $/ \mathrm{ml}$, were between approximately $71 \%$ and $86 \%$ lower considering both test sands (Table 4). A $90 \%$ reduction corresponds to one order of magnitude. The maximum and minimum permeability reductions were achieved for the lowest and highest bacterial cell concentrations investigated respectively. Compared with the controls, $k$ value reductions of between $50 \%$ and $94 \%$ were achieved for sand A treated using the same bacterial solution of $1 \times 10^{8}$ cells $/ \mathrm{ml}$ but different urea and $\mathrm{CaCl}_{2}$ solution concentrations in the ranges $0 \cdot 1-1 \cdot 85$ and $0 \cdot 1-1 \cdot 0 \mathrm{M}$, respectively (Table 3 ). Greater reductions in the permeability coefficient were generally achieved for higher cementation solution concentrations: for example, $k$ value reductions were approximately one order of magnitude greater for $1.85 \mathrm{M}$ urea-1.0 $\mathrm{M} \mathrm{CaCl}_{2}$ compared with $0 \cdot 1 \mathrm{M}$ urea- $0 \cdot 1 \mathrm{M} \mathrm{CaCl}_{2}$. These findings are consistent with Yasuhara et al. (2011). More specifically, from the data in Table 3, it would appear that, for non-equimolar cementation solutions, higher urea molarity produced greater reductions in permeability.

\subsection{SEM analyses}

Figure 6 shows SEM images obtained from the top, middle and bottom portions of a test specimen of sand $\mathrm{A}$ that had been treated with bacterial cell and cementation solutions of $1 \times 10^{8}$ cells $/ \mathrm{ml}$ and $1.85 \mathrm{M}$ urea- $1.0 \mathrm{M} \mathrm{CaCl}_{2}$ (the latter being the highest concentration investigated). Calcite was observed to have deposited at all three locations, indicating that the reagents had distributed/permeated over the full specimen length of $140 \mathrm{~mm}$. Hence, from this point of view, the staged injection (with retention periods) protocol adopted for the main testing programme in the present study was judged a success. However, the distribution of calcite deposition was not entirely uniform over the specimen length. Compared with the specimen midheight, significantly greater amounts of precipitated calcite had formed within the top and bottom portions, appearing to cause significant clogging of the pore voids/throats at these locations (Figures 6(a) and 6(c)). At the specimen mid-height, individual calcite crystals appeared smaller but approximately similar in size (Figure 6(b)). Similar calcite deposition patterns have been observed by van Paassen (2009) over the length of MICP-treated sand columns. Possible reasons for the significantly lower levels of calcite deposition occurring near the specimen mid-height may include a lack of oxygen and (or) reagents present at this location. Oxygen may have an influence on the precipitation rate and characteristics of the calcite crystals formed in the pore voids. Palmén (2012) reported that exposure of MICP-treated sand to air (oxygen) produced further strength improvement. On the other hand, Whiffin (2004) and Mortensen et al. (2011) consider that the urea hydrolysis rate is not adversely affected by lack of oxygen. The investigation of this issue was outside the scope of the present study. However, it was not likely that a lack of reagents was responsible for the significantly lower levels of calcite deposition occurring near the specimen mid-height. This is justified, since, compared with the mid-height, significantly greater amounts of calcite had been deposited in the bottom portion of the specimen (i.e. furthest from the injection point). Hence, it can be postulated that a lack of oxygen may have been responsible for the formation of fewer and smaller calcite crystals near the specimen mid-height; further research is necessary in this regard.

Figure 7 shows SEM images obtained from the top portions of test specimens of sand A (i.e. nearest the injection points) that had been treated with different bacterial cell and cementation solution concentrations. For the same $1.0 \mathrm{M}$ urea $-0.5 \mathrm{M} \mathrm{CaCl}_{2}$ solution (Figures 7(a) and 7(b)), the coverage depth of calcite deposited on the sand grains appeared thinner but more uniform for the lower bacterial concentration of $6 \times 10^{7}$ cells $/ \mathrm{ml}$ (Figure 7(b)). For the higher bacterial concentration of $4 \times 10^{8}$ cells $/ \mathrm{ml}$, concentrated areas of calcite precipitate were observed to have formed on the grain suraces and in the pore voids (Figure 7(a)). These concentrated areas of calcite precipitate only formed at the top portions of these specimens, with significantly less precipitation occurring on sand grains at greater distances from the injection point. This was not the case for the $6 \times 10^{7}$ cells $/ \mathrm{ml}$ bacterial solution. For lower concentrations, the bacteria are less likely to accumulate near injection points (Johnson and Logan, 1996) and more likely to permeate through the specimen, thereby 
Improving sand with microbial-induced

carbonate precipitation

Shahrokhi-Shahraki, Zomorodian, Niazi and

O'Kelly
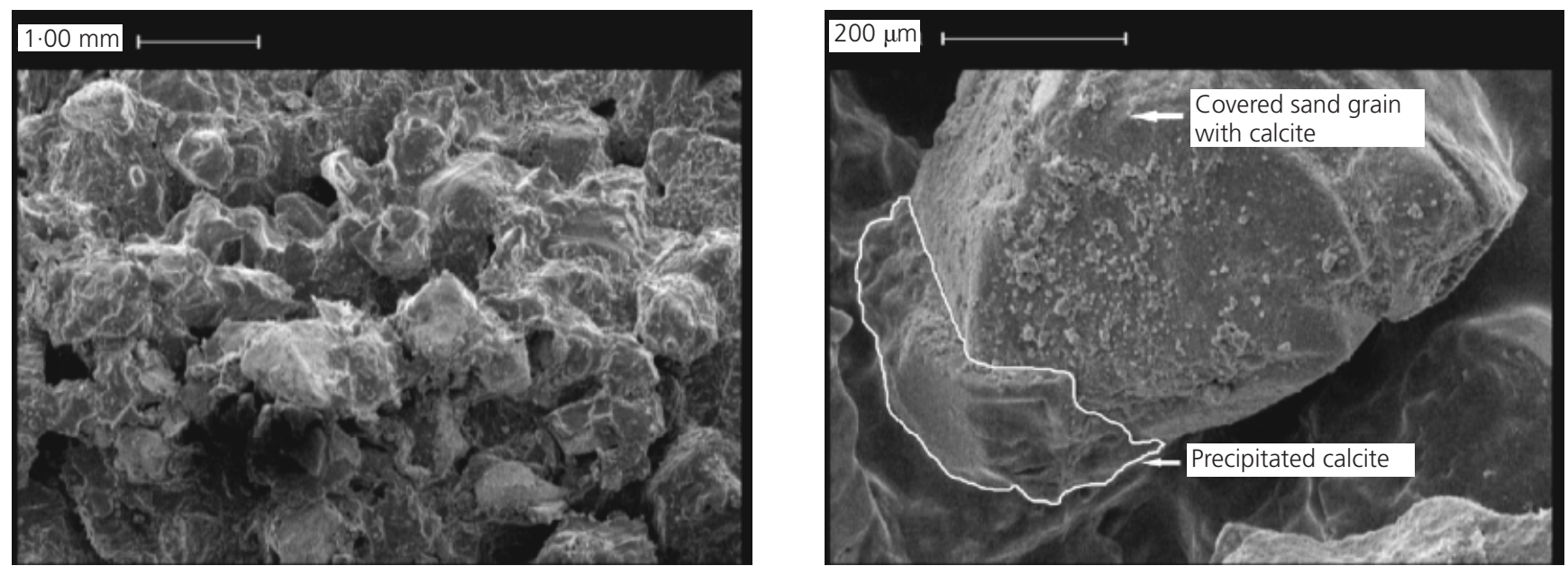

(a)
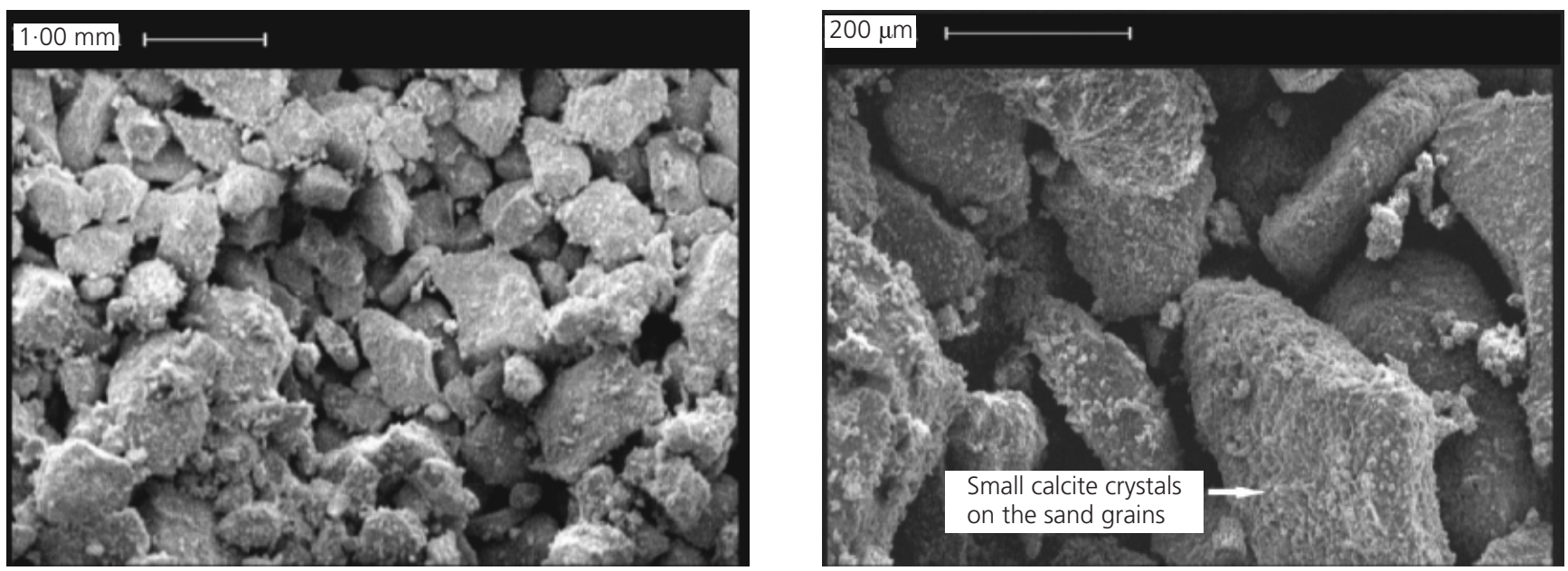

(b)
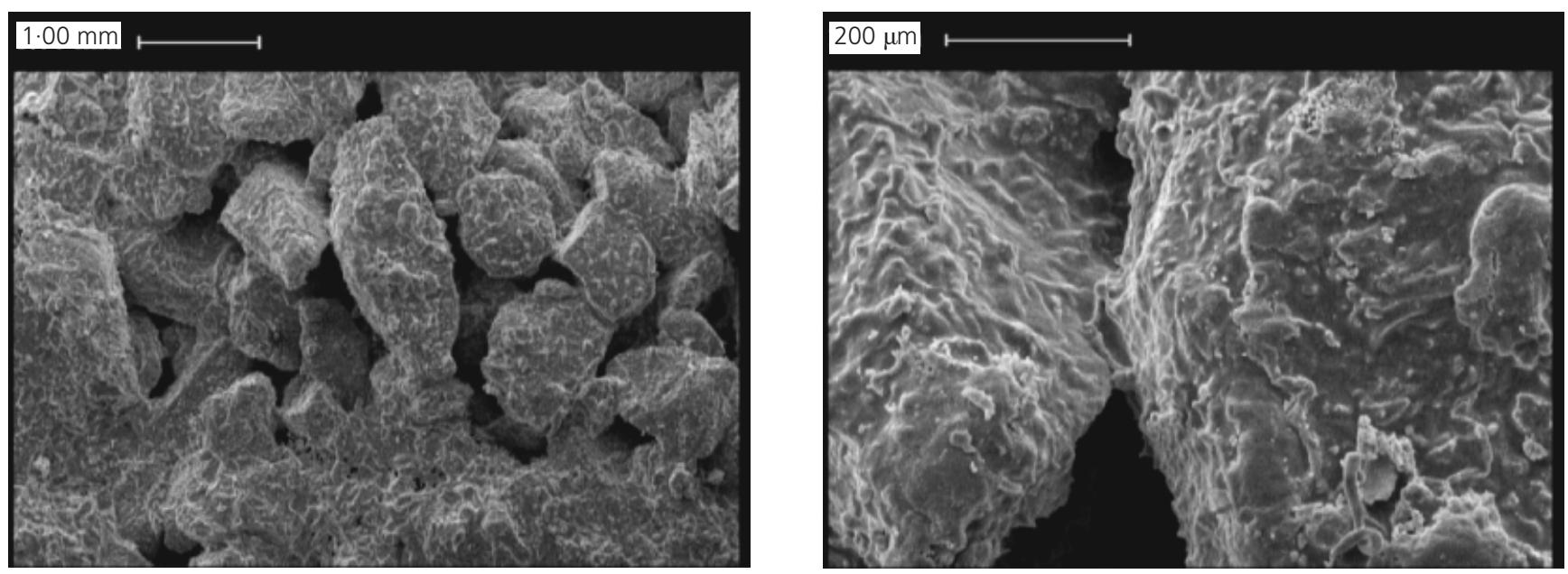

(c)

Figure 6. SEM images of sand A treated with $1 \times 10^{8} \mathrm{cell} / \mathrm{s} / \mathrm{ml}$ bacterial solution and $1.85 \mathrm{M}$ urea-1.0 $\mathrm{M} \mathrm{CaCl}_{2}$ cementation solution: (a) top (nearest the injection point); (b) mid-height; (c) bottom 
Ground Improvement

Volume 168 Issue GI3
Improving sand with microbial-induced carbonate precipitation

Shahrokhi-Shahraki, Zomorodian, Niazi and O'Kelly
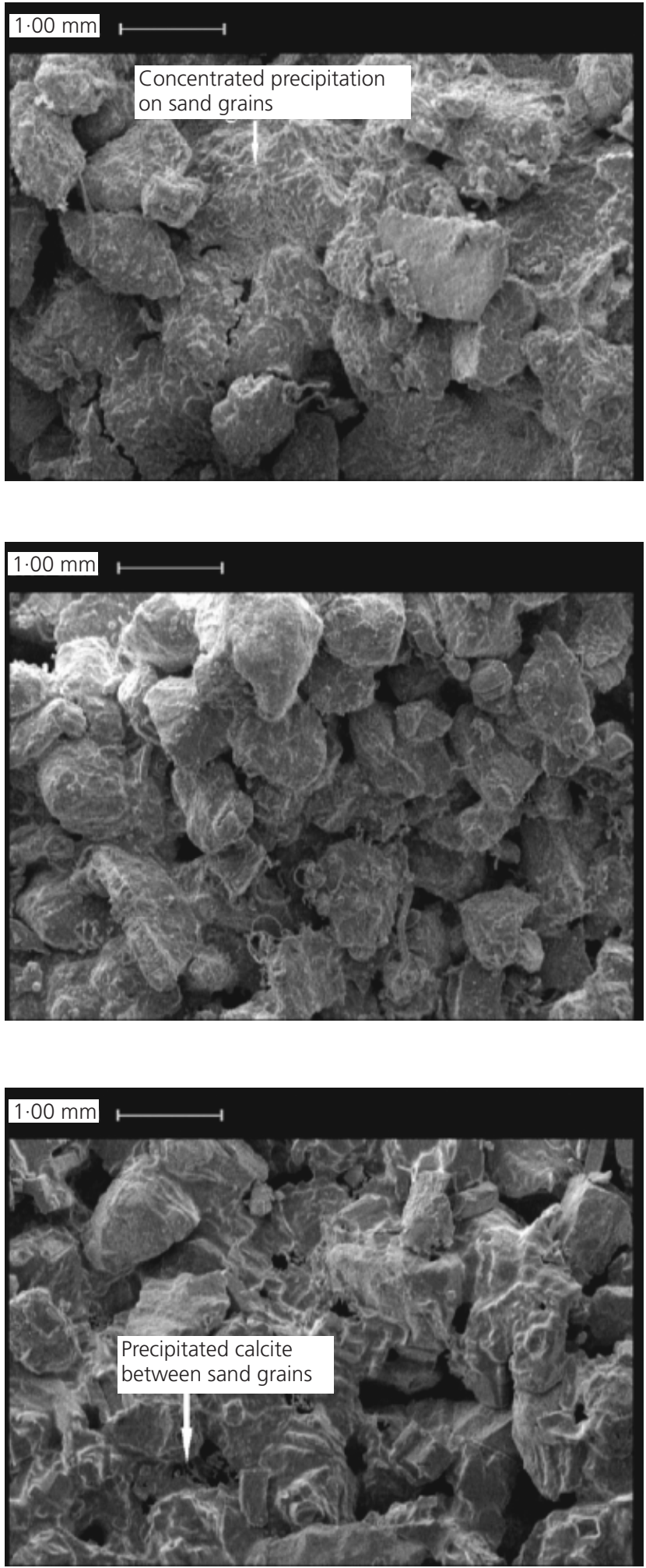

Figure 7. SEM images taken from the top portions of sand $A$ specimens treated with different concentrations of bacterial cell and cementation solutions: (a) $4 \times 10^{8}$ cells $/ \mathrm{ml}$ and $1.0 \mathrm{M}$ urea-

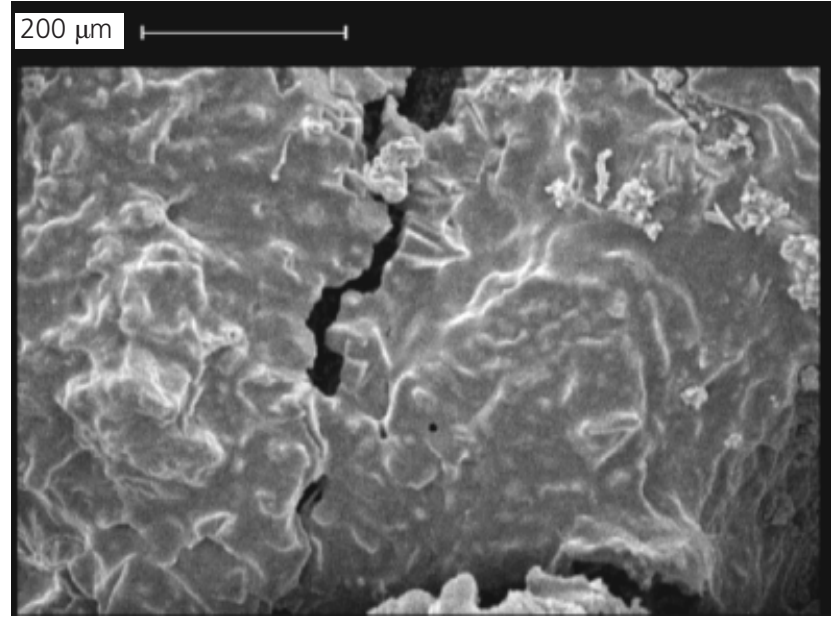

(a)

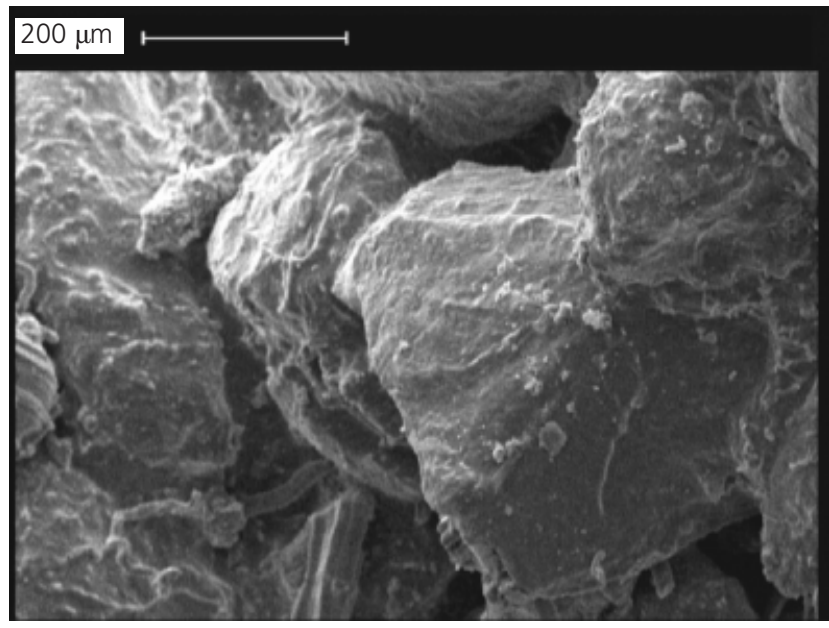

(b)

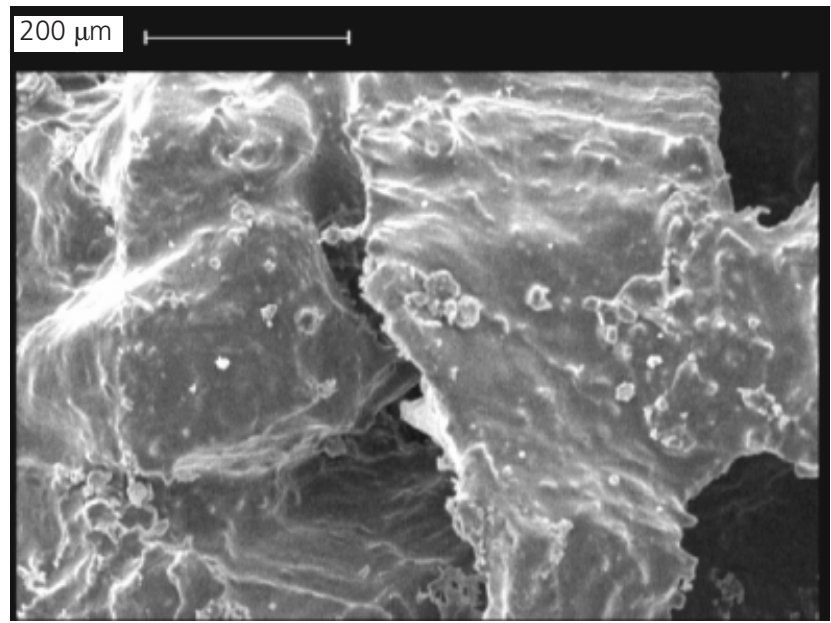

(c)

$0.5 \mathrm{M} \mathrm{CaCl}_{2}$; (b) $6 \times 10^{7}$ cells $/ \mathrm{ml}$ and $1.0 \mathrm{M}$ urea-0.5 $\mathrm{M} \mathrm{CaCl}_{2}$;

(c) $1 \times 10^{8} \mathrm{cells} / \mathrm{ml}$ and $0.25 \mathrm{M}$ urea- $0.25 \mathrm{M} \mathrm{CaCl}_{2}$ 
allowing a more even attachment of bacteria to the sand grain surfaces over the specimen's length.

\section{Discussion}

According to Stocks-Fischer et al. (1999), the level of calcite precipitation reduces for increasing bacterial concentrations above $\sim 10^{8}$ cells $/ \mathrm{ml}$. For the three bacterial solutions of $6 \times 10^{7}$, $1 \times 10^{8}$ and $4 \times 10^{8}$ cells $/ \mathrm{ml}$ investigated in the present study, higher UCS and stiffness values along with greater reductions in permeability coefficient values were achieved for the (lower) $6 \times 10^{7}$ cells $/ \mathrm{ml}$ solution concentration (see Table 4). The distinctly different calcite deposition patterns observed for the different bacterial cell solution concentrations can be explained as follows. For the $4 \times 10^{8}$ cells $/ \mathrm{ml}$ concentration, clogging of the pore voids with bacterial cells occurred close to the injection points (i.e. the tops of the specimens), hampering permeation of the bacterial cell solution along the specimen length under the applied pressure head. On subsequent injection of the cementation solution, calcite deposited as concentrated areas on the grain surfaces and in the pore voids near the tops of the specimens, with the coverage depth on the sand grain surfaces reducing along the specimen length. For the $6 \times 10^{7} \mathrm{cells} / \mathrm{ml}$ concentration, the bacterial solution permeated more easily, and, on injecting the cementation solution, almost uniform calcite precipitation occurred on the grain surfaces (contributing to bond formation) over the full specimen length. This hypothesis is substantiated by the SEM images in Figures 7(a) and 7(b). Hence, in these element tests (i.e. for the specimen as a whole and not just its top portion), higher UCS and lower permeability coefficient values were measured for reducing bacterial cell solution concentrations for both sands that were tested (see Table 4).

For the same bacterial concentration of $1 \times 10^{8}$ cells $/ \mathrm{ml}$, higher UCS and stiffness values along with greater permeability coefficient reductions were achieved for higher cementation solution concentrations (see Table 3). Similar qualitative findings have been reported by Yasuhara et al. (2011) from the MICP treatment of sand using 0.5 and $1.0 \mathrm{M}$ (equimolar) urea- $\mathrm{CaCl}_{2}$ solutions. This may be attributed to the amount and larger size of individual calcite crystals deposited (Al-Thawadi, 2008), which were confirmed by SEM observations in the present study. Comparing the images in Figures 6(a) and 7(c), the greater levels of calcite precipitation for higher-concentration cementation solutions manifested as larger crystal formation on the sand grains and as concentrated deposits in the pore voids. Referring to Table 3, the effect was even greater for non-equimolar urea- $\mathrm{CaCl}_{2}$ solutions comprising a higher molarity urea component. This may be attributable to high specific urease activity (Whiffin, 2004). It is postulated that higher-concentration solutions comprising greater urea molarity produce better (stronger) bonding between sand grains on account of greater levels of calcite precipitation.

Another key factor in modifying the geomechanical and (or) hydraulic properties of sand by MICP is the number of injection cycles. For sand, more injection cycles using high urea- $\mathrm{CaCl}_{2}$ solution concentrations produce greater improvements in geomechanical properties and permeability coefficient reductions (Yasuhara et al., 2011). Al Qabany and Soga (2013) reported that for four treatment cycles, higher cementation solution concentrations over the range $0 \cdot 1-1 \cdot 0 \mathrm{M}$ examined were found to produce more rapid and greater permeability coefficient reductions. This is consistent with the findings of the present study, which investigated a single treatment cycle. However, Al Qabany and Soga (2013) found that, for a greater number of injections, lowconcentration cementation solutions produced stronger specimens for the same amount of calcite precipitation. This apparent contradiction with the present study (i.e. higher UCS and stiffness values were achieved for higher urea- $\mathrm{CaCl}_{2}$ concentrations) may be largely explained by differences between the injection protocols adopted for the two studies. A high number of treatment cycles necessitates the use of low cementation solution concentrations, otherwise UCS and stiffness values are reduced overall on account of non-uniform calcite deposition patterns occurring over the specimen length arising from localised clogging of pore voids close to the injection points. In contrast, for the single-cycle staged injection (with retention periods) protocol adopted for the main testing programme in the present study, greater improvements in stiffness and strength were achieved using higher cementation solution concentrations.

\section{Summary and conclusions}

In this study, different injection strategies for the MICP treatment of sand were investigated at bench scale with varying success. The concentrations of the reagents, especially of the bacterial cell solution (in the range $6 \times 10^{7}$ to $40 \times 10^{8}$ cells $/ \mathrm{ml}$ investigated), were particularly important. Rapid clogging of the pore voids next to the injection points occurred when the reagents were mixing together beforehand and also for single-phase (simultaneous) injection. Clogging of the pore voids was not a particular problem for two-phase injection using lower bacterial cell solution concentrations, but the toughness of the treated sand specimens did not significantly increase away from the injection points, possibly due to leaching/flushing of bacterial cells out of these specimens during subsequent injection of the cementation solution. Staged injection including retention periods and with a pressure head applied during downward injection of the bacterial cell solution proved most effective. For lower bacterial cell solution concentrations, this approach was found to produce a more uniform distribution of calcite crystal formation over greater permeation distances. Single-cycle staged injection along these lines produced significant improvements in the UCS and stiffness values of $140 \mathrm{~mm}$-long test specimens of the two loose medium quartz sands investigated. The permeability coefficient values of the treated sands reduced by less than approximately one order of magnitude, so their drainage capacities were not significantly affected. Greater stiffness/strength improvements and, to a lesser degree, permeability coefficient reductions were achieved for bacterial solution at $6 \times 10^{7}$ cells $/ \mathrm{ml}$ concentration. This was the lower concentration value investigated, and is within the reported range for higher urease activity. Higher cementation solution 
concentrations were also found to produce greater improvements in stiffness/strength, particularly for non-equimolar solutions having a higher molarity of urea. These experimental findings were supported by SEM observations of the treated sands. Stiffer, higher cementation solution concentrations generally produced a more brittle specimen response under unconfined compression. Another factor was grading (particle size), with the finer of the two treated sands investigated mobilising higher UCS and stiffness values.

\section{REFERENCES}

Achal V, Mukherjee A and Reddy MS (2010) Microbial concrete: way to enhance the durability of building structures. Journal of Materials in Civil Engineering 23(6): 730-734.

Al Qabany A and Soga K (2013) Effect of chemical treatment used in MICP on engineering properties of cemented soils. Géotechnique 63(4): 331-339.

Al Qabany A, Soga K and Santamarina C (2011) Factors affecting efficiency of microbially induced calcite precipitation. Geotechnical and Geoenvironmental Engineering 138(8): 992-1001.

Al-Thawadi S (2008) High Strength in-situ Biocementation of Soil by Calcite Precipitating Locally Isolated Ureolytic Bacteria. $\mathrm{PhD}$ thesis, Murdoch University, Perth, Australia.

Bang SS, Galinat JK and Ramakrishnan V (2001) Calcite precipitation induced by polyurethane-immobilized Bacillus pasteurii. Enzyme and Microbial Technology 28(4): 404-409.

BSI (British Standards Institution) (1990) BS 1377: Methods of test for soils for civil engineering purposes. Part 7: Shear strength tests (total stress). BSI, Milton Keynes, UK.

Cheng L, Cord-Ruwish R and Shahin MA (2013) Cementation of sand soil by microbially induced calcite precipitation at various degrees of saturation. Canadian Geotechnical Journal 50(1): 81-90.

DeJong JT, Fritzges MB and Nüsslein K (2006) Microbially induced cementation to control sand response to undrained shear. Geotechnical and Geoenvironmental Engineering 132(11): 1381-1392.

DeJong JT, Mortensen BM, Martinez BC and Nelson DC (2010) Bio-mediated soil improvement. Ecological Engineering 36(2): 197-210.

Dennis ML and Turner JP (1998) Hydraulic conductivity of compacted soil treated with biofilm. Geotechnical and Geoenvironmental Engineering 124(2): 120-127.

Ehrlich HL (1996) Geomicrobiology. Marcel Dekker, New York, NY, USA.

Hammes F, Seka A, De Knijf S and Verstraete W (2003) A novel approach to calcium removal from calcium-rich industrial wastewater. Water Research 37(3): 699-704.

Ismail MA (2000) Strength and Deformation Behaviour of Calcite-cemented Calcareous Soil. PhD thesis, University of Western Australia, Perth, Australia.

Ismail M, Joer H, Randolph M and Meritt A (2002) Cementation of porous materials using calcite. Géotechnique 52(5): 313324.
Ivanov V and Chu J (2008) Applications of microorganisms to geotechnical engineering for bioclogging and biocementation of soil in situ. Reviews in Environmental Science and Biotechnology 7(2): 139-153.

Jardine RJ, Symes MJ and Burland JB (1984) The measurement of soil stiffness in the triaxial apparatus. Géotechnique 34(3): 323-340.

Johnson WP and Logan BE (1996) Enhanced transport of bacteria in porous media by sediment-phase and aqueous-phase natural organic matter. Water Research 30(4): 923-931.

Khatami HR and O'Kelly BC (2013) Improving mechanical properties of sand using biopolymers. Geotechnical and Geoenvironmental Engineering 139(8): 1402-1406.

Le Métayer-Levrel G, Castanier S, Orial G, Loubière JF and Perthuisot JP (1999) Applications of bacterial carbonatogenesis to the protection and regeneration of limestones in buildings and historic patrimony. Sedimentary Geology 126(1-4): 25-34.

Meyer F, Bang S, Min S, Stetler L and Bang S (2011) Microbiologically-induced soil stabilization: application of Sporosarcina pasteurii for fugitive dust control. In Proceedings of Geo-Frontiers 2011: Advances in Geotechnical Engineering, Dallas, TX, USA (Han J and Alzamora DE (eds)). American Society of Civil Engineers, Reston, VA, USA, pp. 4002-4011.

Mitchell JK and Santamarina JC (2005) Biological considerations in geotechnical engineering. Geotechnical and Geoenvironmental Engineering 131(10): 1222-1233.

Montoya B, DeJong J, Boulanger R et al. (2012) Liquefaction mitigation using microbial induced calcite precipitation. In Proceedings of GeoCongress 2012: State of the Art and Practice in Geotechnical Engineering, Oakland, CA, USA (Hryciw RD, Athanasopoulos-Zekkos A and Yesiller N (eds)). American Society of Civil Engineers, Reston, VA, USA, pp. 1918-1927.

Mortensen B, Haber M, DeJong J, Caslake L and Nelson D (2011) Effects of environmental factors on microbial induced calcium carbonate precipitation. Journal of Applied Microbiology 111(2): 338-349.

Nemati M, Greene E and Voordouw G (2005) Permeability profile modification using bacterially formed calcium carbonate: comparison with enzymic option. Process Biochemistry 40(2): 925-933.

O'Kelly BC and Naughton PJ (2008) Local measurements of the polar deformation response in a hollow cylinder apparatus. Geomechanics and Geoengineering 3(4): 217-229.

Okwadha G and Li J (2010) Optimum conditions for microbial carbonate precipitation. Chemosphere 81(9): 1143-1148.

Palmén A (2012) Stabilization of Frictional Soil Through Injection Using CIPS (Calcite in-situ Precipitation System). $\mathrm{PhD}$ thesis, KTH Royal Institute of Technology, Stockholm, Sweden.

Pichan SP and O'Kelly BC (2014) Stimulated decomposition in peat for engineering applications. Proceedings of the ICE Ground Improvement 166(3): 168-176. 
Ramachandran SK, Ramakrishnan V and Bang SS (2001) Remediation of concrete using micro-organisms. $A C I$ Materials Journal 98(1): 3-9.

Rebata-Landa V (2007) Microbial Activity in Sediments: Effects on Soil Behavior. $\mathrm{PhD}$ thesis, Georgia Institute of Technology, Atlanta, GA, USA.

Rong H, Qian CX and Li LZ (2012) Study on microstructure and properties of sandstone cemented by microbe cement. Construction and Building Materials 36: 687-694.

Seki K, Miyazaki T and Nakano M (1998) Effects of microorganisms on hydraulic conductivity decrease in infiltration. European Journal of Soil Science 49(2): 231236.

Soon NW, Lee LM, Khun TC and Ling HS (2013) Improvements in engineering properties of soils through microbial-induced calcite precipitation. KSCE Journal of Civil Engineering 17(4): 718-728.

Stabnikov V, Naeimi M, Ivanov V and Chu J (2011) Formation of water-impermeable crust on sand surface using biocement. Cement and Concrete Research 41(11): 1143-1149.

Stocks-Fischer S, Galinat JK and Bang SS (1999) Microbiological precipitation of $\mathrm{CaCO}_{3}$. Soil Biology and Biochemistry 31(11): 1563-1571.

Tobler DJ, Maclachlan E and Phoenix VR (2012) Microbially mediated plugging of porous media and the impact of differing injection strategies. Ecological Engineering 42: 270-278.

van Paassen LA (2009) Biogrout, Ground Improvement by Microbial Induced Carbonate Precipitation. PhD thesis, Delft University of Technology, Delft, the Netherlands.

van Paassen LA (2011) Bio-mediated ground improvement: from laboratory experiment to pilot applications. In Proceedings of Geo-Frontiers 2011: Advances in Geotechnical Engineering, Dallas, TX, USA (Han J and Alzamora DE (eds)). American Society of Civil Engineers, Reston, VA, USA, pp. 4099-4108.

Viganotti M (2014) Biogrout - Pore Scale Bonding Phenomena in Saturated and Unsaturated Soils. PhD thesis, The University of Dublin, Trinity College Dublin, Dublin, Ireland. Whiffin VS (2004) Microbial $\mathrm{CaCO}_{3}$ Precipitation for the Production of Biocement. PhD thesis, Murdoch University, Perth, Australia.

Whiffin VS, van Paassen LA and Harkes MP (2007) Microbial carbonate precipitation as a soil improvement technique. Geomicrobiology Journal 24(5): 417-423.

Yasuhara H, Hayashi K and Okamura M (2011) Evolution in mechanical and hydraulic properties of calcite-cemented sand mediated by biocatalyst. In Proceedings of Geo-Frontiers 2011: Advances in Geotechnical Engineering, Dallas, TX, USA (Han J and Alzamora DE (eds)). American Society of Civil Engineers, Reston, VA, USA, pp. 3984-3992.

\section{WHAT DO YOU THINK?}

To discuss this paper, please email up to 500 words to the editor at journals@ice.org.uk. Your contribution will be forwarded to the author(s) for a reply and, if considered appropriate by the editorial panel, will be published as a discussion in a future issue of the journal.

Proceedings journals rely entirely on contributions sent in by civil engineering professionals, academics and students. Papers should be 2000-5000 words long (briefing papers should be 1000-2000 words long), with adequate illustrations and references. You can submit your paper online via www.icevirtuallibrary.com/content/journals, where you will also find detailed author guidelines. 